eyesight, who might be expected to respond well to treatment. Our findings show that such early diagnosis will be achieved only rarely if we rely solely on the efforts of patients to contact members of their immediate family.

Patients are usually elderly and are often badly shaken to learn that they have a potentially blinding disease. They may be confused by an explanation about the prescribed regimen of eye drops. Not surprisingly then, even if the doctor remembers to tell them to, many forget to write off to relatives. Clearly, in every eye unit, and possibly in every general practice, someone should take on the responsibility of helping patients with glaucoma to alert members of their family that they also may have the disease.

We thank $\mathrm{Mr} \mathrm{M}$ J Absolon, $\mathrm{Mr}$ I H Chisholm, Mr J I McGill, and $\mathrm{Mr}$ C B Walker for agreeing to our studying patients under their care.

1 Crick RP. Computerised clinical data base for glaucoma-10 years' experience. Research and Clinical Forums 1980;2:29-39.

2 Miller SJH, Paterson GD. Studies on glaucoma relatives. Br f Ophthalmol 1962;46: $513-22$.

Coakes RL. The role of a family glaucoma clinic. Research and Clinical Forums $1980 ; 2.15-9$.

MacKean JM, Elkington AR. Referral routes to hospital of patients with chronic Accepted 11 fuly 1984)

Department of Surgery, University of Southampton SO9 $4 \mathrm{XY}$

J M MACKEAN, BA, DBO, research fellow

A R ELKINGTON, FRCS, senior lecturer

Correspondence to: Mr A R Elkington, Southampton Eye Hospital, Southampton $\mathrm{SO} 9 \mathrm{XW}$.

\section{Hypoxia, depression of testosterone, and impotence in pickwickian syndrome reversed by weight reduction}

Research in our departments has shown low serum testosterone values accompanied by organic sexual impotence in patients with hypoxic chronic obstructive airways disease $\mathrm{e}^{12}$ and pulmonary fibrosis. ${ }^{3}$ A correlation between pressure of arterial oxygen $\left(\mathrm{PaO}_{2}\right)$ and serum testosterone values supported a causal relation, arterial carbon dioxide pressure $\left(\mathrm{PaCO}_{2}\right)$ having been excluded as the factor responsible. ${ }^{13}$ In individual patients testosterone values and sexual potency fluctuated with severity of disease and changes in $\mathrm{PaO}_{2} \cdot{ }^{2-4}$ As patients with hypoxia of obstructive sleep apnoea (pickwickian) syndrome had not been so investigated we performed similar endocrine studies on a man with this condition.

\section{Case report and investigations}

A 58 year old man with no previous illnesses and not receiving drugs presented with a six month history of daytime somnolence and inability to concentrate which developed during weight gain of $20 \mathrm{~kg}$ after stopping smoking when asymptomatic nine months before. Snoring had become accentuated and, whereas sexual intercourse used to occur about twice a week, he had been impotent with no intercourse or early morning penile erections for six months. He was obese, short necked, and cyanosed. As there was no history to suggest chronic bronchitis or emphysema he was considered to have pickwickian syndrome and was admitted for investigation and weight reduction.

Investigations were performed before (day 0 ) and at intervals during a weight reduction diet (days 1-126; see table). Pituitary stress tests were performed on days 0 and 126. Pulmonary function tests and sexual activity were assessed before and after weight reduction. Hormone assay methods were as described ${ }^{3}$ and correlations between $\mathrm{PaO}_{2}$ and various hormone values tested by a least sum of squares linear fit.

Day 0 - Weight was $96.5 \mathrm{~kg}$, forced expiratory volume in one second $\left(\mathrm{FEV}_{1}\right)$ $1.7 \mathrm{l}$, forced vital capacity (FVC) $2.6 \mathrm{l}$, and $\mathrm{FEV}_{1} / \mathrm{FVC} 65 \%$. Responses to injected gonadotrophin releasing hormone $(\mathrm{GnRH})$ at zero, 30, and 60 minutes were: serum luteinising hormone $(\mathrm{LH}) 6.4,23 \cdot 0$, and $20.0 \mathrm{U} / 1$ (normal $<9 \cdot 0,20 \cdot 0-42 \cdot 0$, and $20 \cdot 0-38 \cdot 0 \mathrm{U} / \mathrm{l}$ ) and serum follicle stimulating hormone $(\mathrm{FSH}) 3 \cdot 0,5 \cdot 5$, and $6 \cdot 4 \mathrm{U} / 1$ (normal $<7 \cdot 0,4 \cdot 0-18 \cdot 0$, and $4 \cdot 5-21 \cdot 0$ $\mathrm{U} / 1)$. Responses to injected thyrotrophin releasing hormone (TRH) at zero, 30 , and 60 minutes were: serum thyroid stimulating hormone (TSH) $<1.0,<1.0$, and $<1.0 \mathrm{mU} / 1$ (normal $<8.0 \mathrm{mU} / 1$, increment of $>3.6$ $\mathrm{mU} / 1$, and value less than that at 30 minutes) and serum prolactin concentration 140,300 , and $240 \mathrm{mU} / \mathrm{l}$ (normal $60-360 \mathrm{mU} / \mathrm{l}$, increment of $>65 \%$ of basal value, and value less than that at 30 minutes). Chest $x$ ray picture and electrocardiogram were normal.

Day 126 - Weight was $76 \mathrm{~kg}, \mathrm{FEV}_{1} 2 \cdot 21$, FVC $3 \cdot 21$, and $\mathrm{FEV}_{1} / \mathrm{FVC} 69 \%$ Responses to injected GnRH were: serum LH $4 \cdot 5,32 \cdot 0$, and $28.0 \mathrm{U} / 1$ and serum FSH $5 \cdot 0,12 \cdot 0$, and $13 \cdot 0 \mathrm{U} / \mathrm{l}$. Responses to injected TRH were: serum TSH $<1 \cdot 0,4 \cdot 1$, and $1.8 \mathrm{mU} / 1$ and serum prolactin concentration 60,360 , and $230 \mathrm{mU} / 1$. Sexual intercourse was occurring at least twice weekly and early morning erections had returned.

The table shows the blood gas and serum hormone responses to weight reduction. $\mathrm{PaO}_{2}$ was positively correlated with serum concentrations of testosterone, FSH, triiodothyronine, thyroxine, and sex hormone and thyroid binding globulins.

\section{Comment}

Up to $42 \%$ of men with pickwickian syndrome may be impotent $t^{5}$ yet their sex hormone values have never before been evaluated. In this classic example of the syndrome a reduction of body weight produced improved respiratory function and blood oxygenation accompanied by return to normal of depressed serum testosterone concentrations and sexual activity. We have made similar observations in patients recovering from the severe hypoxia of acute cor pulmonale failure $^{24}$ but, possibly owing to lifelong tolerance to severe hypoxia, have found that men with cyanotic congenital heart disease have no such endocrine disturbance. That profound hypoxia during rapid eye movement sleep fails to occur in these latter patients whereas it does in chronic obstructive airways disease, pulmonary fibrosis, and pickwickian syndrome may also be relevant.

Sequential measurements of body weight, arterial blood gas tensions, and various serum hormone values in man with pickwickian syndrome before (day 0 ) and during weight reduction diet

\begin{tabular}{|c|c|c|c|c|c|c|c|c|c|c|c|c|c|c|}
\hline Day & $\begin{array}{l}\text { Body } \\
\text { weight } \\
\text { (kg) }\end{array}$ & $\begin{array}{l}\mathrm{PaO}_{2} \\
(\mathrm{kPa})\end{array}$ & $\begin{array}{l}\mathrm{PaCO}_{2} \\
(\mathrm{kPa})^{2}\end{array}$ & $\begin{array}{l}\text { Testosterone } \\
(\mathrm{nmol} / \mathrm{l})\end{array}$ & $\begin{array}{l}\text { Sex } \\
\text { hormone } \\
\text { binding } \\
\text { globulin } \\
(\mathrm{nmol} / \mathrm{l})\end{array}$ & $\begin{array}{l}\text { Free } \\
\text { testosterone } \\
\text { index }\end{array}$ & $\begin{array}{l}\text { Calculated } \\
\text { free } \\
\text { testosterone } \\
(\mathrm{pmol} / \mathrm{l})\end{array}$ & $\begin{array}{l}\mathrm{LH} \\
(\mathbf{U} / 1)\end{array}$ & $\underset{(\mathbf{U} / \mathbf{l})}{\text { FSH }}$ & $\begin{array}{l}\text { Triiodothyronine } \\
(\mathrm{nmol} / \mathrm{l})\end{array}$ & $\begin{array}{l}\text { Thyroxine } \\
(\mathrm{nmol} / \mathrm{l})\end{array}$ & $\begin{array}{l}\text { Thyroid } \\
\text { binding } \\
\text { globulin } \\
(\mathrm{mg} / \mathrm{l})\end{array}$ & $\begin{array}{l}\text { Free } \\
\text { thyroxine } \\
(\mathrm{pmol} / \mathrm{l})\end{array}$ & $\begin{array}{l}\mathrm{TSH} \\
(\mathrm{mU} / \mathrm{l})\end{array}$ \\
\hline $\begin{array}{l}0 \\
1\end{array}$ & $96 \cdot 5$ & $\begin{array}{l}5 \cdot 5 \\
6 \cdot 1\end{array}$ & $\begin{array}{l}7 \cdot 3 \\
7 \cdot 5\end{array}$ & $\begin{array}{l}4 \cdot 9 \\
4 \cdot 3\end{array}$ & 29 & $0 \cdot 16$ & 80 & $5 \cdot 0$ & $2 \cdot 6$ & 0.9 & 69 & 7 & 15 & $<1.0$ \\
\hline $\begin{array}{r}2 \\
3 \\
6 \\
7 \\
10 \\
15 \\
57 \\
58\end{array}$ & $\begin{array}{l}89 \cdot 5 \\
86 \cdot 5 \\
85 \cdot 2 \\
78 \cdot 7\end{array}$ & $\begin{array}{l}6 \cdot 0 \\
6 \cdot 4 \\
7 \cdot 9 \\
6 \cdot 9 \\
7 \cdot 6 \\
7 \cdot 7 \\
8 \cdot 8 \\
8 \cdot 4\end{array}$ & $\begin{array}{l}6 \cdot 8 \\
7 \cdot 1 \\
6 \cdot 1 \\
6 \cdot 1 \\
6 \cdot 1 \\
6 \cdot 5 \\
6 \cdot 0 \\
5 \cdot 7\end{array}$ & $\begin{array}{r}5 \cdot 1 \\
5 \cdot 1 \\
8 \cdot 0 \\
9 \cdot 2 \\
14 \cdot 0 \\
15 \cdot 0 \\
17 \cdot 0 \\
22 \cdot 0\end{array}$ & $\begin{array}{l}32 \\
35 \\
50 \\
48 \\
50 \\
58 \\
63\end{array}$ & $\begin{array}{l}0.16 \\
0.15 \\
0 \cdot 16 \\
0.19 \\
0.28 \\
0.26 \\
0.27\end{array}$ & $\begin{array}{r}81 \\
78 \\
100 \\
120 \\
180 \\
180 \\
200\end{array}$ & $\begin{array}{l}8 \cdot 7 \\
6 \cdot 4 \\
4 \cdot 9 \\
4 \cdot 9 \\
9 \cdot 0 \\
5 \cdot 8 \\
5 \cdot 8\end{array}$ & $\begin{array}{l}3 \cdot 0 \\
3 \cdot 0 \\
3 \cdot 4 \\
3 \cdot 2 \\
6 \cdot 0 \\
7 \cdot 2 \\
7 \cdot 2\end{array}$ & $\begin{array}{l}1.3 \\
1.3 \\
1.5 \\
1.5 \\
1.5 \\
1.4 \\
1.3\end{array}$ & $\begin{array}{l}84 \\
67 \\
94 \\
84 \\
96 \\
80 \\
91\end{array}$ & $\begin{array}{r}9 \\
10 \\
11 \\
12 \\
16 \\
13 \\
13\end{array}$ & $\begin{array}{l}14 \\
16 \\
16 \\
17 \\
15 \\
17 \\
18\end{array}$ & $\begin{array}{l}<1.0 \\
<1.0 \\
<1.0 \\
<1.0 \\
<1.0 \\
<1.0 \\
<1.0\end{array}$ \\
\hline 126 & $76 \cdot 0$ & $9 \cdot 2$ & $6 \cdot 1$ & 15.0 & 43 & 0.34 & 210 & $4 \cdot 5$ & $5 \cdot 0$ & $1 \cdot 8$ & 88 & 13 & 18 & $<1.0$ \\
\hline $\begin{array}{l}\text { Normal } \\
\text { range }\end{array}$ & $67 \cdot 0^{*}$ & $\begin{array}{l}10 \cdot 7- \\
13 \cdot 3\end{array}$ & $\begin{array}{l}4 \cdot 7- \\
6 \cdot 0\end{array}$ & $11 \cdot 0-36 \cdot 0$ & $5-45$ & $0 \cdot 3-1 \cdot 8$ & $200-600$ & UD-9·0 & UD-7·0 & $0 \cdot 9-2 \cdot 8$ & $55-144$ & $12-30$ & $9-25$ & UD-8.0 \\
\hline Correlat & tion with & $\mathrm{PaO}_{2}$ & & $\begin{array}{l}r=0.843 \\
p<0.01\end{array}$ & $\begin{array}{l}\mathrm{r}=0.747 \\
\mathrm{p}<0.05\end{array}$ & $\begin{array}{l}r=0.813 \\
p=0.01\end{array}$ & $\begin{array}{l}r=0.866 \\
p=0.01\end{array}$ & $\begin{array}{l}r=0 \cdot 281 \\
N S\end{array}$ & $\begin{array}{l}r=0.703 \\
p<0.05\end{array}$ & $\begin{array}{l}r=0.741 \\
p=0.05\end{array}$ & $\begin{array}{l}r=0.670 \\
p<0.05\end{array}$ & $\begin{array}{l}r=0.730 \\
p<0.05\end{array}$ & $\begin{array}{l}r=0.781 \\
p<0.05\end{array}$ & NS \\
\hline
\end{tabular}

UD = Undetectable. NS $=$ Not significant.

"Ideal weight. Conversion: SI to traditional units- $\mathrm{PaO}_{2}$ and $\mathrm{PaCO}_{2}: 1 \mathrm{kPa} \approx 7.5 \mathrm{~mm} \mathrm{Hg}$. Testosterone: $1 \mathrm{nmol} / 1 \approx 0 \cdot 29 \mathrm{ng} / \mathrm{ml}$. Sex hormone binding globulin: $1 \mathrm{nmol} / 1 \approx 0 \cdot 29 \mathrm{ng} / \mathrm{ml}$. Free testosterone: $1 \mathrm{pmol} / 1 \approx 0.29 \mathrm{pg} / \mathrm{ml}$. Triiodothyronine: $1 \mathrm{nmol} / 1 \approx 0.65 \mathrm{ng} / \mathrm{ml}$. Thyroxine: $1 \mathrm{nmol} / 1 \approx 0.08 \mu \mathrm{g} / 100 \mathrm{ml}$. Free thyroxine: $1 \mathrm{pmol} / 1 \approx 0.8 \mathrm{pg} / \mathrm{ml}$. 
The correlation between $\mathrm{PaO}_{2}$ and serum concentrations of testosterone, FSH, thyroid hormones, and hormone binding globulins suggests a causal association. Normal basal LH and FSH concentrations and normal pituitary responses to injected GnRH in this case and patients with respiratory disease ${ }^{3}$ suggest hypothalamic suppression, though additional hypoxic testicular suppression seems possible. While thyroid hormone values tended to increase with improved $\mathrm{PaO}_{2}$ the rise was less than with testosterone, and in respiratory disease also the hypothalamopituitary-testicular axis seems to be particularly sensitive to hypoxia. Absent TSH responses to injected TRH before weight reduction and their return to normal after diet along with a rise in serum thyroxine concentration suggested reversible pituitary suppression of TSH even though serum thyroxine values were normal throughout. These normal values were also found in occasional instances in our patients with respiratory disease ${ }^{3}$ in the presence of pituitary suppression of TSH.

1 Semple Pd'A, Beastall GH, Watson WS, Hume R. Serum testosterone depression associated with hypoxia in respiratory failure. Clin Sci 1980;58:105-6.

emple Pd'A, Beastall GH, Hume R. Male sexual dysfunction, low serum testosterone and respiratory hypoxia. British fournal of Sexual Medicine 1980;64:48, 3 Semple Pd'A, Beastall GH, Brown TM, Stirling KW, Mills RJ, Watson WS. Sex hormone suppression and sexual impotence in hypoxic pulmonary fibrosis. Thorax $1984 ; 39: 46-51$.

4 Semple Pd'A, Watson WS, Beastall GH, Hume R. Endocrine and metabolic studies in unstable cor pulmonale. Thorax 1983;38:45-9. 5 Guilleminault C, Dement WC. Sleep apnoea syndromes. New York: Alan R Liss,

(Accepted 11 fuly 1984)

Chest Unit, Inverclyde Royal Hospital, Greenock PA16 OXN

PETER D'A SEMPLE, MB, MRCP, consultant physician

ALASTAIR GRAHAM, $M B$, registrar in medicine

YVONNE MALCOLM, SRD, dietitian

Department of Clinical Biochemistry, Royal Infirmary, Glasgow G4 GRAHAM H BEASTALL, PHD, top grade biochemist

Department of Clinical Physics and Bioengineering, Southern General Hospital, Glasgow G51

WALTER S WATSON, PHD, principal physicist

Correspondence to: Dr P d'A Semple.

\section{Fixed drug eruption masquerading as herpes simplex labialis}

Drug eruptions are common, but the true incidence is unknown as many are not reported. Fixed drug eruptions are less common and may not be recognised. We report a case that was misdiagnosed as herpes simplex labialis.

\section{Case report}

A 38 year old woman took Equagesic tablets (aspirin, meprobamate, and ethoheptazine) intermittently for pain in her leg. She developed an erythematous lesion on the left lateral margin of the lower lip and surrounding skin (figure), which became vesicular and resolved after 10 days leaving faint pigmentation. It recurred one month later, and herpes simplex labialis was diagnosed. During the next six months the lesion recurred five times and was eventually accompanied by similar lesions on the dorsum of her hand, thigh, and abdomen. A challenge test to Equagesic and to meprobamate caused a recurrence of the lesions. There was no recurrence after Equagesic was stopped.

\section{Comment}

Fixed drug eruptions characteristically recur at the same sites whenever the offending agent is given. Initially the lesion is erythematous, mildly oedematous, and sometimes vesicular. Afte- seven to 10 days it becomes a dusky violaceous colour, and after repeated attacks the pigmentation may become permanent. Eruptions often occur on the palms and soles but may affect the glans penis and mucous membranes, and the condition comes into the differential diagnosis of oral and genital herpes.

The pathogenesis is unknown, but during the acute phase of the eruption a factor was identified in the serum of 21 affected patients that induced lymphocyte transformation. ${ }^{2}$ Skin transplanted from an affected site to a non-affected site loses its capacity to react, while normal skin transplanted to an affected site becomes reactive. ${ }^{3}$

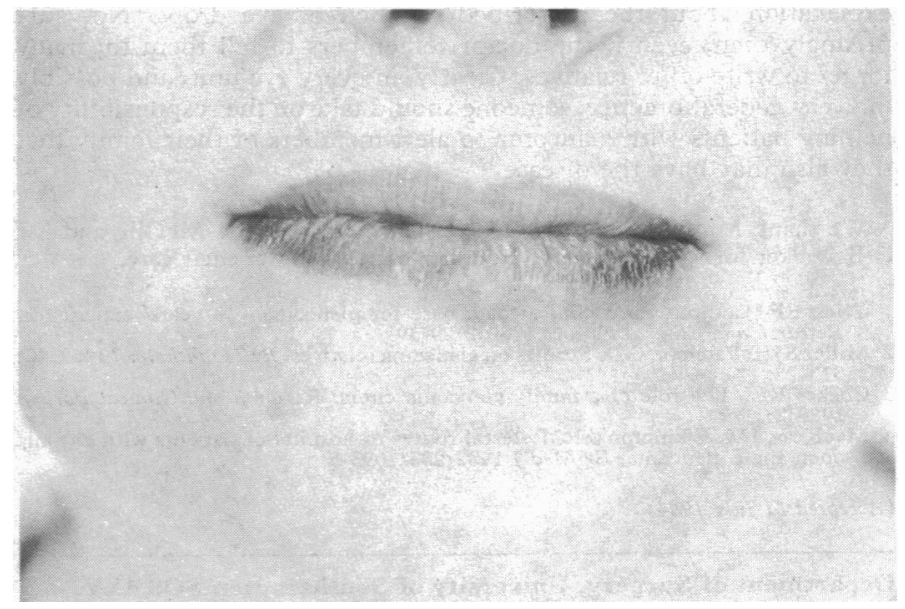

Fixed eruption on left lateral margin of lower lip caused by ingestion of Equagesic.

Fixed drug eruption should be considered when lesions recur at the same site. The drugs associated with fixed drug eruption are as follows:

\section{Commonly implicated}

Barbiturates

Phenolphthalein

Sulphonamides

Phenylbutazone

Sulphonamides
Tetracyclines

Less commonly implicated

Acetarsol

Acriflavine

Amidopyrine

Amoxycillin

Ampicillin

Amylobarbitone

Arsenicals

Aspirin

Atropine

Bisacodyl

Buthalitone

Butobarbitone

Carbromal

Chloral hydrate

Chlordiazepoxide

Chlormezanone

Chlorphenesin carbamate

Codeine

Co-trimoxazole

Cyclizine

Dapsone

Dimethylchlortetracycline

Diphenhydramine

Dipyrone

Disulfiram

Emetine

Erythromycin

Glutethimide

Griseofulvin
Hydroxyurea

Isoaminile citrate

Meprobamate

Methaqualone

Metronidazole

Minocycline

Nystatin

Oxyphenbutazone

Paracetamol

Penicillins

Phenacetin

Phenazone

Phenobarbitone

Phthalylsulphathiazole

Quinine

Salicylates

Succinylsulphathiazole

Sulphadiazine

Sulphadimethoxine

Sulphadimidine

Sulphamerazine

Sulphamethoxazole

Sulphamethoxydiazine

Sulphamethoxypyridazine

Sulphaphenazole

Sulphathiazole

Sulphobromophthalein

Trimethoprim
1 Baker H. In: Rook A, Wilkinson DS, Ebling FJG, eds. Textbook of derma ology. 3rd ed. Oxford: Black:well Scientific Publications, 1979:1121-2.

2 Gimmez-Camarasa JM. Lymphocyte transformation test in fixed drug eruption. $N$ Engl $₹$ Med 1975;292:819-21.

3 Bruinsma W. A guide to drug eruptions. 3rd ed. Oosthuizen, Netherlands: De Zwaluw, 1982:63-7.

(Accepted 17 fuly 1984)

Bristol Royal Infirmary, Bristol BS2 8HW

J BOYLE, MB, MRCP, senior registrar, department of dermatology

B MOUL, MPS, staff pharmacist, regional drug information centre

Correspondence to: Dr J Boyle. 